\title{
H4C9 Gene
}

National Cancer Institute

\section{Source}

National Cancer Institute. H4C9 Gene. NCI Thesaurus. Code C68734.

This gene plays a role in nucleosomal structure. 